\title{
Application Of Game Methods As A Basis For Forming Positive Motivation Of Students Of Non-Philological Higher Educational Institutions
}

Journal Website:

http://usajournalshub.c om/index,php/tajssei

Copyright: Original content from this work may be used under the terms of the creative commons attributes 4.0 licence.

\author{
Mashkhura Aminovna Khafizova \\ Senior Teacher At Samarkand State Architectural And Construction Institute, Independent \\ Researcher (PhD) At Samarkand State Institute Of Foreign Languages, Uzbekistan
}

\section{ABSTRACT}

The purpose of this article is to study and research the methods and forms of using the motivational capabilities of pedagogical games in the process of mastering a foreign speech, in particular the Russian language in non-philological higher educational institutions. The methodology of the article is based on the effective use of various modern pedagogical approaches, accompanied by gaming technologies in the study of Russian as a foreign language. The practical significance of the article lies in the possibility of further application of situational role-playing games, both in psychological and pedagogical activities and in the educational process.

\section{KEYWORDS}

Game, game technologies, motivation, cognitive activity, communicative competence, didactic game.

\section{INTRODUCTION}

"We all know that Uzbekistan has rich natural resources, powerful economic and human potential. But still, our greatest wealth is the enormous intellectual and spiritual potential of our people" [1, p. 39]. 
Modern society needs healthy, positive, energetic and creative people who are moral in relation to themselves and to other people. Currently, teaching Russian as a foreign language is actively developing as a relevant and promising direction. Interest in the study of the Russian language is constantly growing all over the world. Mastering the basics of the Russian language is a prerequisite for performing educational and professional activities while studying at a non-linguistic university.

\section{THE MAIN FINDINGS AND RESULTS}

An urgent problem is to increase the motivation of students to study the Russian language, in particular in a non-linguistic university, to search for methods, techniques and technologies to improve the efficiency of the educational process, as well as to support active verbal communication during classroom lessons. The solution to this problem requires the use of new pedagogical and game technologies. Recently, special attention has been paid to the development of students' creative activity and interest in subjects. Therefore, you and I must also be creative, apply various pedagogical technologies in teaching, which would contribute to the comprehensive development of the student and arouse interest in the subject. These technologies include gaming technologies. We use them to increase the motivation of students in Russian lessons.

Motivation as a complex multi-level heterogeneous system of motivators includes needs, motives, interests, ideals, aspirations, attitudes, emotions, norms, values, etc. Motivation is studied in various aspects, in this regard; the concept is interpreted in different ways. Motivation is defined "as motives that cause the activity of the body and determine its direction" [2, p. 219].

Research by psychologists and educators puts the effectiveness of learning in direct proportion to the motivation for learning. "Among the main tasks currently facing each teacher, there is no other more important and at the same time more difficult than the task of forming students' positive, sustainable motivation, which prompted them to persistent, systematic educational work!" [3,192]. Without motivation for learning, student activities will not be successful. The task of forming motivation for learning is common for all educational institutions. This problem was considered in detail in the works of A.K. Markova, however, her research concerns the formation, diagnosis of the motivation for learning of schoolchildren, and not university students, although it is for them that the motivation for learning has its own specifics, since professional motivation affects the motivation for learning Without exception, all researchers of the game in general and the role-playing game in particular talk about the most important characteristic of the game - a high level of motivation. Motivation is a complex phenomenon. VL Skalkin and OI Yakovenko understand motivation as "a constantly supported student's interest in the very process of mastering a foreign language, its effectiveness" [4, 3, 9]. The more intelligent a person is, the more he should be inclined to play. A communicative game is a learning task that includes language, communication and activity tasks. Play is a specially organized activity that requires exertion of emotional and mental strength. The game always involves making a decision: how to act, what to say, how to win. The desire to find an answer to these questions sharpens the thinking activity 
of the players. In addition, it should be emphasized that the game is a diagnostic tool that allows you to determine the level of professional communicative competence of students, to identify the most problematic areas of the known unknown, to determine the degree of mastering the material. The game helps to revitalize the lesson, arouses interest not only in the issues studied, but also in the Russian language as a school subject. The game provides a higher, in comparison with the usual forms of training, effectiveness. It is especially pleasing that those students who are reluctant to study work with great enthusiasm in such classes. If the lesson is structured in the form of a competition, then each student has a desire to win, and for this they must have good knowledge (they understand this and try to better prepare for the lesson).

The specificity of a non-linguistic university is that a foreign language for students is not the main subject of study. A foreign language is viewed as a tool for the implementation of successful professional activities in a foreign language environment, where the main goal of communication is to achieve mutual understanding. In this case, the task of forming communicative competencies, that is, "the ability to solve a complex of communicative tasks that ensure the goals of communication" $[5,98]$ becomes especially relevant. First of all, the need to use sociolinguistic and communicative approaches is dictated by profound and irreversible changes that have taken place in the modern world in recent decades and have affected all spheres of life.

The game has the following characteristics: "is a type of human activity that can recreate other types of human activity; "A kind of unproductive activity, the motive of which is not the result, but the process itself; "An independent social structure, implying a competition between two or more opposing sides, as well as limited by procedures and rules in order to achieve the victory of one of the parties; "A formally organized system of rivalry between its participants. From an educational point of view, play is a way of group dialogical research of the possibilities of reality in the context of personal interests $[6,5]$.

Games used in the educational process serve to activate the student's activity, develop his cognitive activity, observation, attention, memory, thinking, help maintain interest in what is being studied, develop creative and imaginative thinking, and relieve fatigue from participants. The games used in Russian lessons are varied. The most common games are developed in accordance with the sections of the Russian language. An analysis of educational and methodological complexes in the context of teaching vocabulary in Russian lessons shows that stable and alternative textbooks are aimed at expanding the vocabulary of students, acquaintance with the word as a necessary element that contributes to the formation of functional literacy. Among the shortcomings identified in teaching vocabulary, it is necessary to note the unsystematic principle of the selection of words, leading to difficulties in systematizing the lexical units of the dictionary; lack of clarity in defining the principles of teaching vocabulary; inconsistency of a word with extralinguistic activity; lack of ways to differentiate words. All this allows us to say that the educational and methodological complexes existing today do not make it possible to form the level of mastering practical skills that is necessary in the modern concept of education, which provides for an activity approach. The use of games in the Russian language lesson 
allows you to revitalize the learning process, make it entertaining and creative. Aimed at the psychology of the age-related and individual development of students, gaming technologies make the learning process exciting and interesting, and memorizing, repeating or consolidating information - more emotional.

The main task of the teacher is to reveal the abilities of each student, to bring up a decent and patriotic personality ready for life in a hightech, competitive country. Teaching the subject should be structured so that students can independently set and achieve serious goals, skillfully respond to different life situations. Thus, the current state of education makes it necessary to search for new and nontraditional ways to improve the quality of their theoretical training, readiness for independent creative work, and, most importantly, means and methods, including interactive gaming technologies in the classroom of the Russian language. The game contributes to the development of key competencies of students, the development of creative thinking and the activation of independent work. In the process of games, purposefulness, activity, dynamism and productivity of thinking, strength and efficiency of memory, striving for excellence and self-confidence develop. From the point of view of science, playful learning is promising, because it does not oppose modern pedagogical technologies and is one of the forms of learning. When using gaming technology, the cognitive activity of students develops. Cognitive (didactic) games are specially created situations that simulate reality, from which students are invited to find a way out. The main purpose of this method is to stimulate the process. The student receives such incentives in the game, where he acts as an active transformer of reality.

A didactic game has a definite structure. Structure - these are the main elements that characterize play as a form of learning and play activity at the same time. We consider the following structural components of a didactic game:

1) A didactic task;

2) Game task;

3) Game actions;

4) The rules of the game;

5) Result (summing up).

If in spontaneous play motivation also arises spontaneously, then in didactic play motivation must be created. This is a teacher's task and not an easy task.

\section{CONCLUSION}

In a playful form of training, the problem of communication becomes especially relevant. The game materializes only in communication; it must mobilize the personality to solve the problem of interaction with all participants in the game. Therefore, the socio-psychological aspect of the analysis of the game is of particular importance here. By the nature of the pedagogical process, the following groups of games are distinguished: teaching, training, controlling, cognitive, educational, developing, reproductive, productive, creative, communicative, diagnostic, career guidance. First of all, it is necessary to highlight the type of educational game that meets the requirements of the target audience - students of a non-linguistic university. Note that not all types of games are suitable for teaching a foreign language in a non-linguistic university. 
The game takes a lot of classroom time, and in a non-linguistic university, the number of hours allocated to a foreign language is limited. It should be borne in mind that the level of foreign language proficiency among students of a non-linguistic university may differ significantly even within the same group. Based on the above, the game must meet the following criteria:

a) intensity; b) focus on professionally oriented communication needs of the target audience; c) ease of organization and conduct; d) the possibility of modification by the teacherpractitioner of the game in accordance with different levels of proficiency in a foreign language by students.

Thus, students perceive the game with great interest, and the main reason for this is, of course, the game motivation inherent in every person of any age. In Russian language classes, playful motivation can be used to improve the effectiveness of conventional work methods. Even a small playful element introduced into a regular exercise, even the phrase "Let's play!" instead of the traditional "Do an exercise on the page ..." they introduce an element of game motivation, which greatly increases the efficiency of ordinary types of work.).

\section{REFERENCES}

1. Mirziyoev Sh.M. (2016). We will all together build a free, democratic and prosperous state of Uzbekistan. Tashkent: Uzbekiston. - p. 39. (Мирзиеёв Ш.М. Мы все вместе построим свободное, демократическое и процветающее государство Узбекистан. - Ташкент: Узбекистон,2016. - С.39.)
2. Psychology. Vocabulary. Politizdat. Responsible Edition. A.V. Petrovsky, M.G. Yaroshevsky. - Moscow. 1990. - pp. 219220)Психология. Словарь. Политиздат / Под ред. А.В. Петровского, М.Г. Ярошевского. - М., 1990. - С.219-220.)

3. Markova A.K. (1990). Formation of motivation for learning: Book. for the teacher. Markova A.K., Matis T.A., Orlov A.B. - Moscow: Education. - p. 192. (Маркова А.К. Формирование мотивации учения: Кн. Аля учителя / Маркова А.К., Матис Т.А., Орлов А.Б. М.: Просвещение, 1990. - 192 с.)

4. Skalkin V.L., Yakovenko O.I. (1989). Situational-thematic organization of material for teaching oral speech as a means of increasing motivation in the study of foreign languages. Motivational aspects of vocational education. - Perm. pp. 3-9. (Скалкин В.Л., Яковенко О.И. Ситуативно-тематическая организация материала для обучения устной речи как средство повышения мотивации при изучении ин.яз. // Мотивационные аспекты профессиональноориентированного обучения. Пермь, 1989. с.3-9.)

5. Azimov E.G., Shchukin A.N. (2009). New dictionary of methodological terms and concepts. - Moscow. - p. 98. (Азимов э.Г., Щукин А.Н. Новый словарь методических терминов и понятий. М., 2009 c.98.)

6. Kavtaradze D.N. (2009). Education and play. - Moscow: Education. - p. 5. 
The American Journal of Social Science and Education Innovations (ISSN - 2689-100x)

Published: April 30, 2021 | Pages: 438-443

Doi : https://doi.org/10.37547/tajssei/Volume03Issue04-69

2021: 5.857

OCLC - 1121105668

(Кавтарадзе А.Н. Обучение и игра - М.:

Просвещение, 2009. - с.5)

7. Farfieva K. A. Social Media as a factor in formation of scientific thinking in youth. European Journal of Research and Reflection in Educational Sciences. Vol. 8 No. 10, 2020. - Pp. 52-56. 